\title{
UMA LEITURA DO ESTATUTO DA CIDADE
}

\section{Lívia MaRia ARMENTANo KoENIGSTEIN ZAGO*}

1. Introdução. I. - Aspectos Gerais do Estatuto da Cidade: 1. Diretrizes. 2. Plano Diretor. 3. Instrumentos de Implementação da Política urbana. III. Instrumentos de Urbanização. 1. Parcelamento, Edificação e Utilização Compulsórios. 2. IPTU Progressivo no Tempo. 3. Desapropriação com Pagamento em Títulos (Desapropriação-Sanção). 4. Usucapião Especial de Imóvel Urbano. 5. Direito de Superfície. 6. Direito de Preempção. 7. O Direito de Construir no Estatuto da Cidade: outorga onerosa e transferência. 8. Operações Urbanas Consorciadas. 9. Consórcio Imobiliário. 10. Estudo de Impacto da Vizinhança - EIV; IV. Penalidades; $V$. Outras Disposições e Uma Última Observação 1 . O interesse social como fator diferenciador dos tributos e das tarifas. 2. Uma Última Observação.

\section{I.Introdução}

1. Não é demais afirmar que o ser humano, hoje, mais do que "spiens" é "urbano", o homem da cidade, que vive na cidade, que depende da cidade. A cidade ainda significa o sonho, o "glamour", a fuga, a liberdade. Para ela acorreram dezenas de milhões de pessoas em busca, sobretudo, de sociabilidade e bem-estar.

Pela carência de planejamento, de investimentos, de visão, de uma política séria e adequada, a cidade bem-estar transformou-se em cidade do mal-estar individual e coletivo. Agigantou-se, tornou-se caótica e protagonista de dramas, de miséria, solidão, "stress", de desumanidade.

2. Este panorama aliado, no século passado, ainda tão perto e já tão distante, aos movimentos da sociabilização (dos sentimentos, da propriedade, da empresa), da democratização e do ressurgimento da ênfase nos direitos humanos e sociais são condutores de disposições expressas na Constituição brasileira sobre a função social

* Procuradora Aposentada do Município de São Paulo. 
da propriedade, sobre a urbanização e sobre a exigência de lei federal disciplinadora garantidora da vida nas cidades.

Preâmbulo da Carta Magna refere que a Constituição está fundada no Estado Democrático, destinado a assegurar o exercício dos direitos sociais e individuais, a liberdade, a segurança, o bem-estar, o desenvolvimento, a igualdade e a justiça como valores supremos de uma sociedade fraterna, pluralista e sem preconceitos fundada na harmonia social e comprometida, na ordem interna e internacional, com a solução pacífica da controvérsias.

A erradicação da pobreza e da marginalização, a redução das desigualdades regionais e sociais e a prevalência dos direitos humanos alinham-se entre os princípios fundamentais do Estado brasileiro podemos citar a (arts. $3^{\circ}$, III e $4^{\circ}$, II).

Dentre os direitos e deveres individuais e coletivos, escritos no longo artigo $5^{\circ} \mathrm{da}$ Constituição consta, como valor supremo e geral, a igualdade de todos perante a lei.

Para as observações que teceremos nesta reflexão importa citar o destaque que a Constituição fez da igualdade de homens e mulheres em direitos e obrigações. $O$ realce constitucional teve como escopo arredar a preeminência do homem na sociedade familiar. Não teve, e nem poderia, qualquer intenção discriminatória de minorias homossexuais.

A propriedade privada, garantida pela Constituição como direito fundamental e como um dos princípios da ordem econômica e financeira, está espoliada de seu caráter absolutista e sagrado, herança das Revoluções Francesa e Americana. A propriedade privada sofre o condicionamento da sua função social, urbana e rural, na qual também se inclui a preservação e proteção do meio ambiente (artigos $5^{\circ}$, XXII e XXIII e 170, II e III).

Assim sendo, a função social é elemento integrante e constitutivo do próprio conceito de propriedade, não se admitindo, hoje, falar-se ou conceituar-se a propriedade despedida de sua função social.

Importantíssimo frisar o direito social da moradia, adicionado à Constituição por intermédio da Emenda Constitucional n² 26, de 14 de fevereiro de 2000, de vital importância para a implementação da política urbana (art. $6^{\circ}$ ).

3.A Constituição Federal conferiu à União competência a instituir diretrizes para o desenvolvimento urbano, inclusive habitação, saneamento básico e transportes urbanos (art. 21, XX). Nos artigos 182 e 183 contempla a Política Urbana e o faz da seguinte forma:

- As normas gerais da política urbana são da competência da União, que estabelece as diretrizes para a política de desenvolvimento urbano, cuja finalidade é ordenar o pleno desenvolvimento das funções sociais da cidade e garantir o bem-estar de seus habitantes.

- O Município detém competência exclusiva para executar a política urbana.

- O instrumento básico da política de desenvolvimento e expressão urbana é o Plano Diretor, obrigatório para cidades com mais de 20.000 habitantes.

- Cumpre sua função social o imóvel que atende às exigências do Plano Diretor. 
- Pode o Município, mediante lei específica para área incluída no Plano Diretor, exigir do proprietário do solo urbano não edificado, subutilizado ou não utilizado promover, seguindo os ditames da lei federal, seu adequado aproveitamento, sob pena, sucessivamente, de: parcelamento ou edificação compulsórios: imposto sobre a propriedade predial e territorial urbana progressiva no tempo e desapropriação como sanção, cujo pagamento será feito com títulos da dívida pública com prazo de resgate de até dez anos, assegurado o valor real da indenização e os juros legais.

- institui a usucapião urbana, conferindo o título de domínio ao possuidor de imóvel urbano de até duzentos e cinqüenta metros quadrados, homem ou mulher, ou a ambos, independentemente de seu estado civil, utilizado para sua moradia ou de sua família, pelo período de cinco anos ininterruptos sem oposição, desde que não seja proprietário de outro imóvel, urbano ou rural. $O$ direito é conferido uma única vez ao mesmo possuidor.

É neste panorama que surge, após longa tramitação, a Lei $\mathrm{n}^{\circ} 10.257$, de 10 de julho de 2001, autodenominada Estatuto da Cidade, que estabelece normas que regulam o uso da propriedade urbana em prol do bem coletivo, da segurança e do bem-estar dos cidadãos, bem como do equilibrio ambiental.

É uma lei muito bem vinda, aspirada por nós, criaturas urbanas, e inspirada nos ditames e objetivos da Constituição Brasileira.

É uma lei que inova, ao adotar instrumentos legais mais adequados à realidade urbana, muitos deles importados de países onde a urbanização está avançada e vem sendo desenvolvida há bastante tempo, como é o caso da Espanha. Podemos citar como exemplo o direito de preempção conferido ao Poder Público, a outorga onerosa e da transferência do direito de construir, as operações urbanas consorciadas, da figura do EIV (estudo de impacto da vizinhança), dentre outros.

É uma lei merecedora de encômios, podendo transformar-se em indispensável instrumento de racionalização e humanização da cidade.

No entanto tornou-se tímida em razão do veto presidencial aos artigos 15 a 20 do Projeto, que previa a concessão de uso especial de uso para fins de moradia, cujos contornos traçaremos logo a seguir.

A concessão especial para fins de moradia foi a forma justa encontrada pelo legislador de, atendendo às necessidades sociais, atenuar a norma do artigo $183, \S$ $3^{\circ}$, da Constituição Federal, que proíbe usucapião de imóveis públicos. Identicamente, procura implementar a garantia de moradia que consta do artigo $6^{\circ}$, da Carta Magna.

Atribui-se gratuitamente ao homem ou à mulher (o Projeto deveria usar o termo pessoa), independente do estado civil, a concessão do direito de moradia, transmissível aos herdeiros que residam no imóvel por ocasião da abertura do inventário. tal direito não é renovável ao mesmo possuidor.

Os requisitos para a concessão do direito de moradia são objeto do vetado artigo 15: aquele que possuir como sua área ou edificação urbana de até duzentos e 
cinqüenta metros quadrados situada em imóvel público, por cinco anos, ininterruptamente e sem oposição, utilizando-a para sua moradia ou de sua família, tem o direito à concessão de uso especial para fins de moradia à referida área ou edificação, desde que não seja proprietário ou concessionário de outro imóvel, urbano ou rural.

Ainda sobre a concessão especial do direito de moradia releva mencionar que a obtenção do título dar-se-á por via administrativa ou por judicial, nas hipóteses de recusa ou omissão da Administração. É de observar-se que a simples recusa administrativa não induz, necessariamente, em obtenção do título via judicial. A recusa há que ser contrária à lei.

Para a concessão especial do direito de moradia aproveitam-se as norma do usucapião especial, especialmente os artigos 11,12 e 13 .

Importante notar que o desvio da finalidade da moradia, pelo concessionário, autoriza o Poder Público a extinguir o direito de concessão, retornando-lhe o imóvel. O mesmo ocorre com a hipótese de os concessionários remembrarem seus imóveis.

$O$ veto do Senhor Presidente ao instituto da concessão de uso especial para fins de moradia recebeu elogios e críticas. Aqueles que se alinharam favoravelmente ao veto entendem que, no futuro, medida provisória ou lei específica deverá determinar e individualizar a área a ser objeto da concessão.

Não pensamos assim. Sabe-se que a concessão de uso especial para fins de moradia tem que ser precisa e corretamente avaliada $e$ as áreas muito bem delineadas.

No entanto, seria um instrumento muito forte e bastante oportuno para regularizar áreas onde se instalaram, há considerável tempo, favelas que são, na realidade, verdadeiras cidades dentro da cidade!

E não nos parece, por outro lado, que tal matéria possa revestir-se, desde agora, da indispensabilidade e de urgência projetadas para o futuro, de tal sorte que possam, juridicamente, embasar a edição de medida provisória.

Também não careceria, instituto tão necessário, ficar no aguardo, quiçá, de mais doze anos para a aprovação de lei específica!

Vamos além: a Lei ${ }^{\circ} 10.257$, de 10 de julho de 2001 , deixou escapar, outrossim, a oportunidade de regular, de forma moderna e eficiente, como é indispensável, o processo da desapropriação de imóveis urbanos, inclusive para harmonizar-se com a Lei da Responsabilidade Fiscal.

Ao disciplinar a usucapião especial de imóvel urbano e a concessão de uso especial para fins de moradia limitou-se a lei a copiar mecanicamente a letra da Constituição Federal, descuidando de uma interpretação sistêmica e material, fato que teve como conseqüência excluir os parceiros homossexuais, o que constitui ofensa ao princípio fundamental da igualdade e rechaça a garantia constitucional ao direito social de moradia.

\section{II - Aspectos Gerais Sobre o Estatuto da Cidade}

1. As diretrizes gerais do Estatuto da Cidade encontram-se nos artigos $2^{\circ}$ e $3^{\circ}$. As mais expressivas são: 
- Garantia do direito a cidades sustentáveis, para o presente e para as futuras gerações. A sustentabilidade concerne com o direito à terra urbana, à moradia, ao saneamento ambiental, à infra-estrutura urbana, ao transporte, ao serviço público, ao trabalho e ao lazer. Como se vê, é grandiosa a garantia perpetrada pela lei e que se projeta para o futuro. Grandiosa e vaga, como a expressão garantia ao serviço público, alinhado juntamente com o saneamento ambiental, o transporte e a infra-estrutura urbana, que também são serviços públicos. Talvez fosse mais adequado garantir o serviço público, enfatizando o saneamento ambiental, o transporte e a infra-estrutura urbana.

- Gestão democrática das cidades, pela participação popular nos planos, programas e projetos de desenvolvimento urbano. A gestão democrática da cidade será assegurada, dentre outros, por: $a$ ) órgãos colegiados de política urbana e conferências sobre assuntos de interesse urbano (níveis nacional, estadual e municipal); $b$ ) debates, audiências e consultas públicas; $c$ ) iniciativa popular de projeto de lei e de planos, programas e projetos de desenvolvimento urbano.

Foi objeto de veto o referendo popular e plebiscito, que constavam como hipóteses de gestão democrática da cidade.

- Audiência pública do Poder Público municipal e da população nos processos de implantação de empreendimentos ou atividades com efeitos potencialmente nocivos sobre o meio ambiente natural ou construído, o conforto ou a segurança da população (art. 43).

- O controle social está instituído na lei em diversas hipóteses, em especial no que concerne às despesas demandadas com os instrumentos de urbanização utilizados pelo Município, como: planos, planejamentos, plano diretor, zoneamento, desapropriação, servidão, tombamento, instituição de unidades de conservação.

É interessante observar que a sociedade poderá efetuar controle sobre o valor das desapropriações. Este controle não é sobre a oportunidade e conveniência da desapropriação, mas sobre o valor da transação forçada. $O$ controle, outrossim, deverá ser exercido com relação ao direito de preempção, que será analisado adiante.

- Regularização fundiária e urbanização de áreas ocupadas por população de baixa renda, mediante estabelecimento de normas especiais de urbanização e ocupação do solo e edificação, além da simplificação da legislação sobre o uso e ocupação do solo, objetivando possibilitar maior e melhor oferta imobiliária de lotes e unidades habitacionais.

- Participação e cooperação isonômica entre os setores públicos (que a Lei das Cidades denomina "governos", expressão que entendemos devesse ce- 
der lugar à palavra “Administração", por mais técnica, abrangente e adequada) e privados, no processo de urbanização.

- Planejamento do desenvolvimento urbano, evitando a deterioração e corrigindo as distorções existentes.

- ordenação e controle do uso do solo, atendendo aos interesses sociais.

- Integração e complementaridade entre as áreas urbanas e rurais.

\section{O Plano Diretor}

O Plano Diretor é o instrumento básico da política de desenvolvimento e da expansão urbana e tem papel primordial na efetivação da função social da propriedade urbana, que ocorre quando esta atende às exigências fundamentais de ordenação da cidade expressa no plano diretor, assegurando o atendimento às necessidades dos cidadãos quanto à qualidade de vida, à justiça social e ao desenvolvimento das atividades econômicas (art. 39).

Deverá englobar o território do Município como um todo e, sendo parte integrante do processo de planejamento municipal, suas diretrizes e prioridades deverão estar incorporadas ao Plano Plurianual, à Lei de Diretrizes Orçamentárias e ao Orçamento Anual.

Importa anotar que a Lei de Responsabilidade Fiscal (Lei $\left.n^{\circ} 101 / 2000\right)$ disciplina, expressamente, que a criação, expansão ou aperfeiçoamento de ação governamental que acarrete aumento de despesa, deverão vir acompanhadas de estimativa do impacto orçamentário-financeiro no exercício em que deva entrar em vigor e nos dois subsequientes, bem como de declaração do ordenador da despesa de que o aumento tem adequação orçamentária anual e compatibilidade como plano plurianual e com a lei orçamentária. E que estas providências constituem condição prévia para a desapropriação de imóveis urbanos a que se refere o $\S 3^{\circ}$, do artigo 182 , da Constituição Federal (art. 16, $\S 4^{\circ}$, inciso II, da Lei Complementar $n^{\circ} 101 / 2000$ ).

$\mathrm{O}$ Estatuto da Cidade determinou, com muita oportunidade, às cidades que obrigatoriamente devem ter Plano Diretor (segundo a Lei, cidades com mais de 20.000 habitantes e cidades que pretendem implementar os institutos previstos no $\S$ $4^{\circ}$, do art. 182, da Constituição Federal), que o aprovem no prazo de cinco anos, se não tiverem Plano Diretor já aprovado na data da entrada em vigor do Estatuto da Cidade (art. 50).

Em todas as hipóteses, o Plano Diretor deverá ser revisto a cada dez anos $\left(\S 3^{\circ}\right.$ de art. 40).

À obrigatoriedade contida na Constituição Federal ( $\$ 1^{\circ}$ do art. 182$)$ de existência de Plano Diretor para municípios com mais de 20.000 habitantes, o Estatuto da Cidade acrescentou outras hipóteses.

Segundo suas disposições, passa o plano Diretor a ser indispensável, também, às cidades integrantes de regiões metropolitanas e regiões urbanas e áreas de especial 
interesse turístico, às cidades que pretendem utilizar-se dos institutos previstos no $\S$ $4^{\circ}$, do art. 182, da Constituição Federal, bem como a cidades inseridas na área de influência de empreendimentos ou atividades com significativo impacto ambiental de âmbito regional ou nacional.

Esta extensão da obrigatoriedade de existência de Plano Diretor, intentada pelo Estatuto da Cidade, para outras hipóteses diversas da previsão constitucional parece-nos de muito duvidosa constitucionalidade, por estar impedida de criar, sem expressa previsão ou permissão constitucional, obrigatoriedade que a Lei Maior não contempla.

O conteúdo mínimo do Plano Diretor deverá abranger a delimitação das áreas onde poderá ser aplicado o parcelamento, edificação ou utilização compulsórios; disposições sobre o direito de preempção, outorga onerosa do direito de construir, fixação de áreas onde se permitirá a alteração do uso do solo em troca de contrapartida do beneficiário, operações urbanas consorciadas e transferência do direito de construir.

Também é indispensável que o Plano Diretor preveja um sistema de acompanhamento e controle.

3.0 Estatuto da Cidade traz inovações e institutos jurídicos importantes que servem como instrumento à implementação da política urbana.

Estes instrumentos estão divididos em: $a$ ) planos nacionais, regionais e estaduais de ordenação do território e do desenvol vimento econômico e social; $b$ ) planejamento das regiões metropolitanas, aglomerações urbanas e microrregiões; $c$ ) planejamento municipal; $d$ ) institutos jurídicos e políticos; $e$ ) estudo prévio do impacto ambiental (EIA), estudo prévio de impacto de vizinhança (EIV) e consórcios imobiliários.

Oportuno destacar a possibilidade, assinalada pela lei, da contratação coletiva da concessão de direito real de uso de imóveis públicos na hipótese de programas e projetos habitacionais desenvolvidos por órgãos ou entidades da Administração Pública com atuação específica na área (art. $4^{\circ}$ ).

\section{III - Instrumentos de urbanização}

O Estatuto da Cidade cuida, especificamente, dos seguintes instrumentos de urbanização: parcelamento, edificação ou utilização compulsórios; do IPTU progressivo no tempo; da desapropriação com pagamento em títulos (estes três institutos são utilizados em ordem necessariamente sucessiva e crescente da gravidade do descumprimento da função social da propriedade); da usucapião especial de imóvel urbano; do direito de superfície; do direito de preempção; da outorga onerosa do direito de construir; das operações urbanas consorciadas; da transferência do direito de construir; do estudo de impacto de vizinhança.

\section{Parcelamento, edificação ou utilização compulsórios}

O parcelamento, edificação ou utilização compulsórios é medida cabível nas hipóteses de imóveis urbanos não edificados, subutilizados ou não utilizados. A 
necessidade de adequação do imóvel à sua finalidade social depende de lei específica para área incluída no plano diretor que fixará as condições e os prazos para o cumprimento da obrigação.

O prazo mínimo que a lei poderá fixar para a implementação da obrigação é de um ano, a partir da notificação, para que seja protocolado o projeto perante a Prefeitura e de dois anos, após a aprovação do projeto, para o início das obras. Não fixa a lei prazo para a conclusão das obras e nem determina que o órgão municipal o faça, atendendo às especificidades e dimensão do empreendimento, o que nos parece grave falha, vez que poderá possibilitar retardo ou a paralisação da obra por parte dos proprietários, sem sanção própria para tal fato.

Abre o Estatuto uma exceção para empreendimentos de grande porte, qual seja, a possibilidade de previsão da conclusão da obra em etapas. Também aqui não há referência à fixação de prazo, valendo, a respeito, a mesma observação crítica feita acima.

É evidente o escopo da lei de evitar o domínio privado de bens imóveis na cidade sem aproveitamento social. O proprietário do imóvel subutilizado, assim entendido aquele imóvel com aproveitamento inferior ao mínimo definido em lei será notificado pessoalmente para dar-lhe a devida utilização. Tal notificação será averbada no Registro de Imóveis.

Foi oportuno o veto presidencial que excluir, das hipóteses de subutilização do imóvel seu aproveitamento em desacordo com a legislação urbanística ou ambiental.

Observa-se a preocupação do legislador de determinar que a notificação seja pessoal, procedia por funcionário. Frustrada, após três tentativas, a notificação pessoal, esta será feita por edital. Não disciplina a lei o número de ditas do edital e nem o veículo de comunicação escrita a ser utilizado.

Neste ponto entendemos que a lei poderia ter previsto, também, a notificação pelo correio ou por meios eletrônicos, o que flexibilizaria e agilizaria o processo.

Louvável o dispositivo do artigo $6^{\circ} \mathrm{da}$ Lei, pelo qual a transmissão do imóvel, por ato inter vivos ou causa mortis após a notificação transfere, sem interrupção de prazos, as obrigações de parcelamento, edificação ou utilização do bem.

\section{IPTU progressivo no tempo 3. Desapropriação com pagamento em títulos (desapropriação-sanção)}

Descumpridas as condições e prazos previstos para a construção, utilização ou adequaço do imóvel subutilizado, o Município aplicará a progressão do IPTU no tempo, aumentando sua alíquota no período de cinco anos.

O valor da alíquota, fixado por lei, não poderá exceder o dobro do valor referente ao ano anterior e tem como teto a alíquota de $15 \%$.

A tributação progressiva no tempo impede concessão de anistia ou isenções.

O não cumprimento, pelo proprietário, de dar funcionalidade social ao imóvel, implica em duas consequiências: permanece a cobrança do IPTU pela alíquota máxima e possibilita ao Município efetivar a desapropriação-sanção. 
É de observar-se não ser obrigatório que o Município promova a desapropriação-sanção. Esta vem disciplinada na lei como uma garantia conferida ao Poder Público municipal.

Na hipótese de o Município optar pelo recebimento do IPTU progressivo, após os cinco anos consecutivos, é de observar-se que a não opção pela desapropriação com pagamento em títulos pode ser uma opção que não atenda às finalidades sociais da cidade e o espírito do Estatuto.

Assim sendo, uma vez que há, nos termos do $\S 5^{\circ}$, do artigo $8^{\circ}$, a possibilidade de o Município expropriar o imóvel com pagamento em títulos da dívida pública, vendendo-o ou concedendo-o a terceiros, para a finalidade de dar cumprimento à função social da propriedade seria conveniente que a lei exigisse do Município justificar expressamente sua opção pela interrupção da sucessão prevista constitucionalmente, ando ensejo à comunidade de conhecer, discutir e controlar os motivos de sua escolha.

\section{Usucapião especial de imóvel urbano}

Ao disciplinar o usucapião urbano, o Estatuto traz duas regras: possibilita que o herdeiro legítimo continue na posse do antecessor, desde que já resida no imóvel por ocasião da abertura da sucessão e institui a figura do usucapião coletivo.

O usucapião coletivo atende a um fato urbano, consistente na ocupação conjunta, indiscriminada e indeterminada (condomínio), por famílias de baixa renda de áreas com mais de $250 \mathrm{~m} 2$.

Nesta hipótese, o Estatuto diz: as áreas urbanas com mais de duzentos $e$ cinqüenta metros quadrados, ocupadas por população de baixa renda para sua moradia, por cinco anos, ininterruptamente e sem oposição, onde não for possivel identificar os terrenos ocupados por cada possuidor, são susceptíveis de serem usucapidas coletivamente, desde que os possuidores não sejam ocupantes de outro imóvel urbano ou rural.

A usucapião coletiva será declarada por sentença judicial, que servirá como título para o registro no Cartório de Registro de Imóveis. Na sentença o juiz instituirá condomínio, atribuindo a cada possuidor fração ideal de terreno, independente da dimensão do terreno que ocupe, salvo se houver acordo (escrito) entre os condôminos estabelecendo frações diferenciadas.

O Estatuto da Cidade institui a ação de usucapião especial urbana, de rito sumário, cujos pontos mais relevantes são: tem capacidade processual ativa, dentre outros, a associação de moradores da comunidade, como substituto processual; na pendência da de usucapião especial ficarão sobrestadas outras ações, petitórias ou possessórias, que venham a ser propostas relativamente ao imóvel usucapiendo. A lei não faz qualquer referência às ações em curso quando da propositura da ação especial de usucapião urbana, exceto que a ação especial poderá ser invocada como matéria de defesa, valendo a sentença que a reconhecer como título para registro no Cartório de Registro de Imóveis. 
Está garantido, no Estatuto, ao autor da ação usucapião especial urbana, o benefício da gratuidade da Justiça e da Assistência Judiciária, gratuidade extensiva ao Cartório de Registro de Imóveis.

\section{Direito de superfície}

É um instituto que permite que o proprietário, por escritura pública, gratuita ou onerosa, transfira ao superficiário, por tempo determinado ou indeterminado, o direito de utilização do solo, do subsolo e do espaço aéreo do terreno, atendida a legislação urbanística.

É de observar-se a separação que o Estatuto faz entre a propriedade e o direito de uso do imóvel, cabendo notar que este é um meio de dar atendimento à função social da cidade e, dos institutos que o Estatuto traz como novidade, é o único que disciplina relação que pode abranger particular e particular.

As normas sobre o direito de superfície, objeto dos artigos 21 a 24 do Estatuto não trazem maiores novidades.

\section{Direito de preempção}

O direito de preempção consiste em preferência, instituída em favor do Poder Público, na aquisição de imóvel urbano objeto de alienação onerosa entre particulares.

Este dispositivo legal possibilita que o Poder Público dê, ele próprio, destinação social ao imóvel. O artigo 26 do Estatuto impõe a obrigatoriedade do exercício do direito de preempção, por parte do Município, todas as vezes que ocorrerem os casos taxados. Não se cuida, portanto, de mera possibilidade do exercício da preferência. Trata-se de verdadeira obrigação do Poder Público. $O$ direito de preempção será exercido sempre que o Poder Público necessitar de áreas para...

Não se podia afirmar, antes do veto presidencial, serem taxativas as hipóteses, em face da grande abrangência da última delas (justamente a que foi convenientemente vetada), que admitia o exercício do direito de preempção nos casos onde se verificassem finalidades de interesse social ou de utilidade pública definidas no Plano Diretor.

Agora, as situações contempladas são taxativas: regularização fundiária; execução de programas e projetos habitacionais de interesse social; constituição de reserva fundiária, ordenamento e direcionamento da expansão urbana; implantação de equipamentos urbanos e comunitários; criação de espaços públicos de lazer e áreas verdes; criação de unidades de conservação ou proteção de outras áreas de interesse ambiental; proteção de áreas de interesse histórico, cultural ou paisagístico.

O Plano Diretor passa a ter importância capital no cumprimento e na efetivação da função social da propriedade. Podemos afirmar que o Plano Diretor tem a função importantíssima de possibilitar a efetivação da própria função social da cidade.

$O$ instituto da preempção permite que o Poder Público crie um estoque de imóveis de interesse social, como é o caso da constituição de reserva fundiária, do ordenamento e direcionamento da expansão urbana. 
O direito de preempção pode ser exercido tantas vezes quantas forem as transações onerosas realizadas no imóvel, no espaço máximo de cinco anos.

Se o proprietário desejar alienar a terceiro o imóvel passível do exercício do direito de preempção pelo Poder Público, nos termos do artigo 27 do Estatuto, passa a ter algumas obrigações. Inclusive, se a transação for realizada diversamente dos termos constantes da proposta, é nula de pleno direito.

Deverá o proprietário:

a) Notificar o município da intenção de alienar o imóvel.

Esta notificação tem por objetivo obter a manifestação do Poder Público sobre sua intenção quanto à aquisição do imóvel. A opção pela compra do bem, nos termos da proposta, deverá ser publicada em órgão da imprensa oficial ou, no mínimo, em um jornal local ou regional de grande circulação e terá validade pelo prazo de trinta dias. O transcurso do prazo sem manifestação do Poder Público libera o proprietário para vendê-lo a terceiros, mas nas condições da proposta apresentada.

b) à notificação será anexada proposta de compra por terceiro, da qual deverá constar o preço, condições e validade; $c$ ) vendido o imóvel a terceiro, está o proprietário obrigado a apresentar o instrumento público de alienação ao Poder Público, no prazo de trinta dias. O Estatuto não esclarece o termo inicial dos trinta dias, o que entendemos devesse constar expressamente.

Já ao Poder Público compete fazer publicar edital de aviso da notificação recebida pelo proprietário, contendo a manifestação de sua intenção de adquirir o bem, nos termos da proposta.

A partir da data da publicação da notificação recebida no Diário Oficial começa a correr, para o Poder Público, o prazo de trinta dias para exercer sua preferência sobre a compra; silente o Poder Público depois de transcorrido este prazo, o proprietário fica livre para alienar o imóvel;

O valor a ser pago pelo Poder Público é o do IPTU ou a quantia indicada na proposta apresentada, se superior ao IPTU.

\section{Outorga onerosa do direito de construir no Estatuto da Cidade: outorga} onerosa e transferência.

Em países onde o Direito Urbanístico tem bastante desenvolvimento e relevo, há previsão de que o direito de propriedade do solo não está, necessariamente, vinculado ao direito de construir. Citamos novamente aqui o exemplo da Espanha.

Nossa carta Magna dispõe pertencer à União, constituindo propriedade distinta da propriedade do solo, para efeito de exploração, as jazidas, em lavra ou não e demais recursos minerais e os potenciais de energia hidráulica (art. 176).

Não há previsão constitucional quanto à possibilidade do solo ser distinta do direito de construir, pertencendo este ao Município nas hipóteses previstas no Plano Diretor ou em leis específicas.

No entanto, o Estatuto da Cidade contempla duas possibilidades concernentes ao direito de construir: a outorga onerosa do direito de construir (arts. 28 a 31 ) e a transferência do direito de construir (art. 35). 
A outorga do direito de construir na possibilidade de o proprietário do imóvel obter a elevação do coeficiente de aproveitamento básico ${ }^{1}$ adotado ou alteração de uso, em troco de contrapartida a ser prestada pelo beneficiário.

Lei Municipal específica preverá os cálculos para a cobrança, a contrapartida e os casos passíveis de isenção do pagamento da outorga.

Os recursos advindos pelo recebimento, pelo Poder Público, em razão da outorga, serão obrigatoriamente aplicados às seguintes finalidades: regularização fundiária; execução de programas e projetos habitacionais de interesse social; constituição de reserva fundiária; ordenamento e direcionamento da expansão urbana; implantação de equipamentos urbanos e comunitários; criação de espaços públicos de laser e áreas verdes e de unidades de conservação ou proteção de outras áreas de interesse ambiental; proteção de áreas de interesse histórico, cultural ou paisagístico e outras finalidades de interesse social ou de utilidade pública definidas no Plano Diretor.

A Lei 10.257, de 10 de julho de 2001 merece elogios pela instituição de regras concernentes com a outorga onerosa do direito de construir, que guarda semelhança com as conhecidas "operações interligadas".

No entanto deveria, a nosso ver, ter previsão sobre a obrigatoriedade do controle, por parte do Poder Público, da exigência de real e completa efetivação da contrapartida, abrindo também neste caso, possibilidade para o controle social.

O Estatuto da Cidade contempla, outrossim, a possibilidade, mediante expressa autorização legal, de o proprietário do imóvel público ou privado, por escritura pública, exercer, em outro local o direito de construir previsto no Plano Diretor ou na legislação urbanística, quando seu imóvel for necessário à implantação de equipamentos urbanos e comunitários, à preservação, quando servir a programas de regularização fundiária, urbanização de áreas ocupadas por população de baixa renda e habitação de interesse social.

\section{Operações urbanas consorciadas}

Nos termos do $\S 1^{\circ}$, do artigo 32, do Estatuto da Cidade, considera-se operação urbana consorciada o conjunto de intervenções e medidas coordenadas pelo Poder Público municipal, com a participação dos proprietários, moradores, usuários permanentes e investidores privados, com o objetivo de alcançar em uma área transformações urbanísticas estruturais, melhorias sociais e a valorização ambiental.

Alguns pontos merecem destaque, no que se refere às operações urbanas consorciadas:

- Poderão prever modificações de índices e características de parcelamento, uso e ocupação do solo e do subsolo, alterações das normas edilícias e a regularização das construções, reformas ou ampliações que estejam em desconformidade com a legislação em vigor.

1 Coeficiente de aproveitamento = relação entre a área edificáveis e a área do terreno. 
- A lei específica das operações urbanas consorciadas deverá conter, entre outros elementos elencados no artigo 33 do Estatuto da Cidade, a contrapartida a ser exigida dos proprietários, usuários permanentes e investidores privados que se beneficiarem das alterações e/ou regularizações.

- O valor da contrapartida deverá ser aplicado exclusivamente na própria operação e seu controle obrigatoriamente compartilhado com representação da sociedade civil.

- O Município poderá emitir CEPACs (Certificados de Potencial de Adicional de Construção). Estes CEPACs podem: $a$ ) ser livremente negociados em leilão, mas conversíveis em direito de construir apenas na área objeto da operação; $b$ ) utilizado como forma de pagamento das obras necessárias à operação $\mathrm{e} c$ ) utilizados no pagamento de área de construção além dos limites permitidos, observado o máximo fixado pela lei específica da operação urbana consorciada.

\section{Consórcio Imobiliário}

Tem previsão nas "Disposiçōes Gerais do Estatuto da Cidade" (art. 436). Consiste numa faculdade, concedida ao Poder Público, a pedido do proprietário atingido pelo parcelamento, edificação ou utilização compulsórios, objetivando viabilizar financeiramente o aproveitamento do imóvel.

O consórcio imobiliário é, portanto, a forma de viabilização de Planos de urbanização ou edificação por meio do qual o proprietário transfere ao Poder Público municipal seu imóvel e, após a realização das obras, recebe, como pagamento, unidades imobiliárias devidamente urbanizadas ou edificadas.

O valor das unidades imobiliárias que retornarão ao proprietário corresponderá ao valor do imóvel antes da execução das obras, refletindo a base de cálculo do IPTU e não compreenderá expectativas de ganhos, lucros cessantes e juros compensatórios.

O instituto do consórcio imobiliário é muito importante para a implementação da função social da propriedade e da própria cidade e é um instrumento relevante do urbanismo e da urbanização.

Por isto estranho e inconveniente vir tão oculto na teia das normas das "Disposições Gerais do Estatuto da Cidade".

Melhor que estivesse inserido juntamente com as disposições referentes ao parcelamento, edificação ou utilização compulsórios. Deveria, outrossim, ser objeto de disciplinamento mais cuidadoso contemplando, por exemplo, a obrigatoriedade de prazo para cumprimento da obrigação de construir, por parte do Poder Público e de pagar o proprietário com as unidades imobiliárias, bem como a consequiência, para o Município, do descumprimento de sua obrigação do cumprimento fora tempo assinado pela lei. 
O estudo de impacto de vizinhança - EIV - vem disciplinado nos artigos 30 a 37 do Estatuto, que remete à lei específica municipal a definição dos empreendimentos e atividades, privados ou públicos, que deverão submeter-se ao estudo deste impacto como condição para a obtenção de licenças ou autorizações para construir, ampliar ou funcionar.

O EIV, que não dispensa a necessidade do estudo prévio de impacto ambiental, — EIA - , nos casos em que este é legalmente exigido, deverá ter análise abrangente de todos os aspectos do empreendimento ou atividade, incluindo o estudo, no mínimo, o seguinte: adensamento populacional, equipamentos urbanos ou comunitários; uso e ocupação do solo; valorização imobiliária; geração de tráfego e demanda por transporte público; ventilação e iluminação; paisagem urbana e patrimônio natural e cultural.

Nada obstante não tenha, o Estatuto, dado uma dimensão ao que se pode entender por vizinhança, referindo, tão-somente, à qualidade de vida da população residente na área e suas proximidades, cremos que deve ser entendida a vizinhança num sentido bastante amplo, sobretudo quando o impacto decorrer de perturbações e possibilidade de poluição ao meio ambiente, sob todas as suas formas.

\section{IV-Penalidades}

O artigo 52 do Estatuto da Cidade destaca, com a ressalva da punição de outros agentes públicos envolvidos, que o Prefeito incorre em improbidade administrativa, prevista na Lei $\mathrm{n}^{\circ} 8.249$, de 02 de junho de 1992, além de outras cabíveis, em três situações:

$1^{\text {a }}$ : Referente ao controle social:

a) não garantir, na qualidade de Chefe do Executivo, a promoção de audiências públicas e debates com a participação da população e seus representantes, bem como a obrigatória publicidade e acesso, a qualquer interessado, de documentos e informações produzidas.

Foi alvo de veto a hipótese de improbidade consistente em impedir ou deixar de garantir a participação de comunidades, movimentos e entidades da sociedade civil no controle de dispêndio de recursos públicos decorrentes da utilização de instrumentos previstos no Estatuto para a implementação da política urbana;

$2^{\text {a }}$ Com relação ao cumprimento de prazos: o Prefeito tem a obrigação de promover a aprovação do Plano Diretor no prazo de cinco anos contados da entrada em vigor do Estatuto da Cidade (se o Município não tiver, nesta data, Plano Diretor aprovado) revendo-o a cada dez anos a partir da lei que o instituiu. $O$ não cumprimento destes prazos implica em improbidade administrativa. 
$3^{\text {a }}$ Com relação à aplicação de recursos: incide em improbidade administrativa o Chefe do Executivo que utilizar áreas obtidas com o exercício do direito de preempção ou recursos provenientes de outorga onerosa do direito de construir ou de operação urbana consorciada em desacordo com as finalidades legais contempladas.

\section{V-Outras Disposições e Uma Última Observação}

\section{O interesse social como fator diferenciador dos tributos e das tarifas.}

Dispõe o artigo 42 do Estatuto da Cidade que os tributos sobre imóveis urbanos, assim como as tarifas relativas a serviços públicos urbanos, serão diferenciados em função do interesse social.

A norma impõe a obrigatoriedade de diferenciação de tributos e tarifas em função de um conceito muito abrangente e difuso, qual seja, o interesse social.

Não se percebe ou apreende com clareza a diç̧ão e extensão de tal dispositivo.

Uma primeira questão se coloca: o que poderia ficar afastado do conceito de interesse social no âmbito da política urbana, por essência social?

Este dispositivo, também encaixado nas "Disposições Finais" da Lei, merece atenção e cuidado: sendo, como de fato são, de interesse social, todos os fatos urbanos, em princípio poder-se-ia, erroneamente aliás, entender possível e leal a ilação no sentido de que a diferenciação dos impostos, taxas, contribuição de melhoria e serviços urbanos em razão do interesse social é atividade discricionária e livre de específico respaldo constitucional.

O dispositivo, por isto mesmo, é de incerta constitucionalidade.

De fato, o interesse social não é, constitucionalmente, fator diferenciador do IPTU, mas, sim: $a$ ) a operacionalização da propriedade como função social, que possibilita a tributação progressiva no tempo como sanção (art. $\left.182, \S 4^{\circ}\right) ; b$ ) o valor do imóvel (art. 156, $\S 1^{\circ}$, I) e $c$ ) a localização e uso do imóvel (art. 156, $\S 1^{\circ}$, II).

Melhor seria simplesmente, a abolição de tal artigo do Estatuto a Cidade.

\section{Uma última observação}

O Estatuto da Cidade insere, entre seus objetivos, a promoção da segurança do cidadão. Esta segurança, seja da cidade, seja na cidade não vem, no entanto, contemplada ou disciplinada em nenhum momento pela lei, o que nos parece falha lamentável.

Mas o estatuto da Cidade é uma lei muito bem vinda.

Mas que tem que ser daquelas leis que "pegam" para o Poder Público, maior responsável pela possibilidade de uma vida digna, segura e adequada para o habitante da cidade e também maior responsável pela efetivação função social da própria cidade! 


\section{A Teoria Geral do Direito e o Marxismo}

E. B. Pasukanis

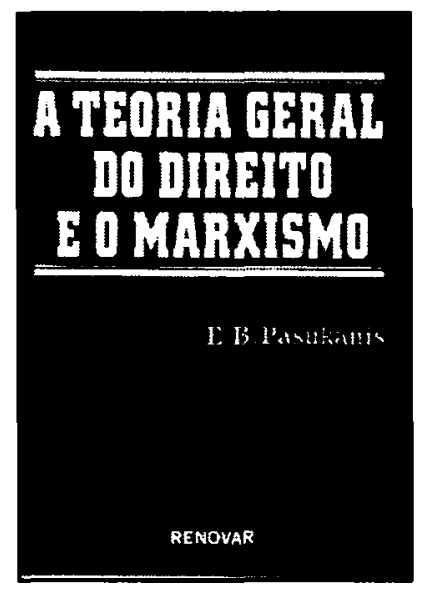

Obra indispensável para todos que pensam o Direito de forma crítica e democrática. $O$ autor realiza sua investigação partindo do pressuposto de que o Direito é uma forma necessária da sociedade capitalista e que surge em consequêencia de determinado nível de desenvolvimento das forças produtivas e das relaçōes daí decorrentes. Este livro reveste-se de real importância aos estudiosos do Direito, que terão em mãos um instrumento capaz de propiciar aos setores democráticos da sociedade uma nova visão do fenômeno jurídico.

Ref. $0015 \quad$ Brochura 378 págs.

Form. 14x21 1989

\section{Cartas Constitucionais \\ Império, República \& Autoritarismo (Ensaio, Crítica e Documentação)}

Neste livro, o autor examina, com o indispensável olhar crítico, alguns dos momentos mais densamente significativos dessa história, tal como ela se refletiu nas cartas constitucionais.

Ref. 131

Brochura

Form. 14x21 1997

Marcello Cerqueira

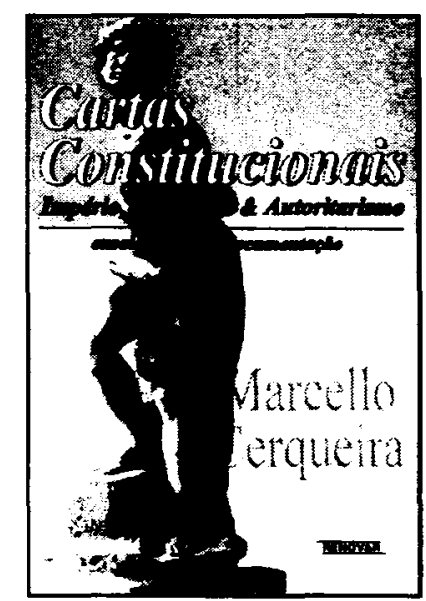

